\title{
Prenatal diagnosis of rare genetic conditions at a tertiary care hospital in Karachi
}

\author{
Kouser Karim \\ Aga Khan University \\ Dhanwanti Dileep \\ Aga Khan University, dhanwanti.dileep@aku.edu \\ Shama Munim \\ Aga Khan University, shama.munim@aku.edu
}

Follow this and additional works at: https://ecommons.aku.edu/

pakistan_fhs_mc_women_childhealth_obstet_gynaecol

Part of the Obstetrics and Gynecology Commons

\section{Recommended Citation}

Karim, K., Dileep, D., Munim, S. (2020). Prenatal diagnosis of rare genetic conditions at a tertiary care hospital in Karachi. JPMA. The Journal of the Pakistan Medical Association, 70(4), 724-727.

Available at: https://ecommons.aku.edu/pakistan_fhs_mc_women_childhealth_obstet_gynaecol/203 


\section{Prenatal diagnosis of rare genetic conditions at a tertiary care hospital in Karachi}

Kouser Karim, Dhanwanti Dileep, Shama Munim

\begin{abstract}
This study aims to observe the spectrum of Prenatal Diagnosis of Rare Genetic conditions at a Tertiary care hospital in Karachi. This is a retrospective review conducted at the Aga Khan University Hospital, Karachi from January 2016 to July 2018. All cases undergoing invasive testing by Chorionic villus sampling for indications other than Thalassemia were included. Forty percent of patients in our cohort underwent invasive testing for muscular dystrophies particularly survival motor neuron (SMN) gene deletion and 32\% for Cystic Fibrosis. Other rare disorders like JAM 3 mutation, PEX 1 gene, Barters Syndrome, Wardenberg, Bardet-Beidl Syndrome and Lissencephaly accounted for $28 \%$. Sophistication in laboratory technology and DNA banking has improved the prenatal diagnosis of rare genetic disorders particularly SMN gene deletion. Integrated care involving foetal medicine specialist, Paediatric geneticist, and dedicated Laboratory personnel improves Counseling and Diagnosis of rare genetic conditions. Provision of dedicated nursing staff along with strengthening of welfare facility for nonaffording patients would improve the uptake of invasive testing.
\end{abstract}

Keywords: CVS (chorionic villous sampling, SMN (Survival motor neuron), SMA (spinal muscular atrophy).

\section{https://doi.org/10.5455/JPMA.11601}

\section{Introduction}

Chromosomal abnormalities and genetic disorders are among the important causes of perinatal morbidity and mortality. ${ }^{1}$ The prevalence of genetic disorders has been increasing worldwide. ${ }^{1}$ It is even more common in the under developed countries like Pakistan primarily due to consanguinity and high birth rate. ${ }^{2}$ Consanguinity accounts for 61.3 per cent of cases being more common in rural than urban setting. ${ }^{3}$

Thalassemia is the leading single gene defect followed by

Department of Obstetrics and Gynecology, Aga Khan University Hospital, Karachi, Pakistan.

Correspondence: Shama Munim. Email: shama.munim@aku.edu
Cystic fibrosis. ${ }^{4}$ Globally, there are 80 million carriers of $\beta$ thalassemia. Around 5000-9000 children are born each year with $\beta$-thalassemia in Pakistan (9.8 million carriers in the total population). ${ }^{5}$ The frequency of delta F508 del in cystic fibrosis patients is $60 \%$ in Pakistan. ${ }^{6}$

Other genetic disorders include survival motor neuron (SMN) gene deletion and Duchene and Spinal muscular dystrophies. SMN is an autosomal recessive neurodegenerative disorder in which there is progressive degeneration of alpha motor neurons leading to muscle atrophy and paralysis. ${ }^{7-9}$ The exact prevalence of SMN gene in our population is still not known but is seen in relatively high numbers in the Genetics and Foetal Medicine clinics.

Prenatal diagnosis of Genetic disorders is made by invasive testing with Chorionic villous sampling (CVS). ${ }^{10}$ The procedure is commonly used for the diagnosis of Thalassemia and Cystic Fibrosis. More recently this procedure is being used for rare genetic disorders in particular SMN deletion. In addition the Laboratory is providing the service of DNA banking. CVS is a preferred method as the amount of DNA extracted is more as compared to Amniocentesis. ${ }^{11,12}$ It has a miscarriage rate comparable to amniocentesis in expert hands. ${ }^{13,14}$

This study describes the spectrum of rare genetic disorders and their diagnosis at our Foetal Medicine unit in collaboration with Paediatric Geneticist and Laboratory. The findings will be helpful in future counseling of patients and streamline referrals.

\section{Methods}

This is a retrospective review conducted at the Aga Khan University Hospital, Karachi, Pakistan from 1st January 2016 to 31 st July 2018. We included all cases undergoing invasive testing by CVS for genetic conditions other than Thalassemia. A prior Ethical Review Committee approval was obtained.

The Aga Khan University is a private sector tertiary referral hospital in Karachi and carries out more than 5800 deliveries annually. A third of these are high-risk pregnancies. The University has four secondary care hospitals with 15000 deliveries annually. The 
Obstetric department is backed up with a wellequipped state of the art 24 bedded Neonatal Intensive Care Unit (NICU).

Foetal medicine unit at the Aga Khan University caters for all high risk pregnancies. The unit is one of the first centers in Pakistan. More than 4000 ultrasound scans are performed annually. Apart from inter and intradepartmental referrals the unit receives patients from all over the country and some of the neighbouring countries like UAE and Afghanistan. The services provided include first trimester screening, genetic sonography, invasive testing and genetic counseling.

In the recent years the Chorionic Villus sampling has been made available for the diagnosis of genetic conditions other than Thalassemia. This is mainly due to the availability of DNA banking at our hospital. The procedure of CVS is preferably performed from 12 weeks of gestation onwards

Data was collected on pre-structured questionnaire from hospital medical records. Data were entered and analyzed by SPSS v. 20.0. Descriptive analysis was done and frequencies were calculated for different indications of CVS and their outcomes.

\section{Results}

Table-2: CVS results for different indications other than thalassemia.

\begin{tabular}{|c|c|c|c|c|}
\hline Indication for CVS & Heterozygous & Homozygous & Normal & Inconclusive \\
\hline Cystic Fibrosis & $6(75 \%)$ & & $2(25 \%)$ & \\
\hline SMN gene & $4(50 \%)$ & $1(12.5 \%)$ & $2(25 \%)$ & $1(12.5 \%)$ \\
\hline Muscular dystrophy & - & & $2(100 \%)$ & \\
\hline \multicolumn{5}{|l|}{ Other genetic disorders } \\
\hline - JAM 3 mutation & 1 & & - & \\
\hline - PEX 1 gene & - & & 1 & \\
\hline - PW 569 gene (Nemaline Myopathy) & - & & 1 & \\
\hline - Barters Syndrome & - & & 1 & \\
\hline - Wardenberg syndrome & - & & 1 & \\
\hline - Bardet-biedel syndrome & 1 & & & \\
\hline • Lissencephaly & & 1 & & \\
\hline
\end{tabular}

Table-3: Outcome of CVS cases.

\begin{tabular}{|c|c|c|c|c|c|c|c|}
\hline & $\begin{array}{l}\text { Livebirth } \\
\text { n (\%) }\end{array}$ & $\begin{array}{c}\text { Miscarriage } \\
\mathbf{n}(\%)\end{array}$ & $\begin{array}{l}\text { TOP } \\
n(\%)\end{array}$ & $\begin{array}{l}\text { IUD } \\
n(\%)\end{array}$ & $\begin{array}{l}\text { NND } \\
\text { n (\%) }\end{array}$ & $\begin{array}{l}\text { Lost to follow up } \\
n(\%)\end{array}$ & $\begin{array}{c}\text { Ongoing pregnancies } \\
\text { n (\%) }\end{array}$ \\
\hline Cystic Fibrosis & - & - & - & - & - & $5(62.5 \%)$ & $3(37.5 \%)$ \\
\hline SMN gene & $2(25 \%)$ & $1(100 \%)$ & $1(100 \%)$ & & - & $1(12.5 \%)$ & $3(37.5 \%)$ \\
\hline Muscular dystrophy & $1(12.5 \%)$ & - & & - & - & $1(12.5 \%)$ & - \\
\hline Other genetic disorders & $4(62.5 \%)$ & - & - & - & - & $1(12.5 \%)$ & $2(25 \%)$ \\
\hline Total & $7(28 \%)$ & $1(4 \%)$ & $1(4 \%)$ & 0 & 0 & $8(32 \%)$ & $8(32 \%)$ \\
\hline
\end{tabular}

TOP: Termination of Pregnancy. IUD: Intrauterine Death. NND: Neonatal Death, SMN: Survival Motor Neuron. 
not be determined among which 9 (36\%) are with ongoing pregnancies and $8(32 \%)$ cases were lost to follow up as they were only referred to the tertiary care for prenatal diagnosis.

\section{Discussion}

Genetic disorders are emerging as the important causes of perinatal morbidity and morbidity. ${ }^{1}$ Worldwide the prevalence of single gene disorders is $10 / 1000$ births (WHO 2013). The most common being thalassemia followed by cystic fibrosis. ${ }^{4}$

SMN gene deletion is among the less commonly diagnosed disorder. The global prevalence of which is around 1-2 per 100,000.8 The carrier frequency of SMN is 1 in 35 to 1 in 50 in the general population. ${ }^{15,16} \mathrm{~A}$ higher prevalence of SMA has been reported in Iran, Saudi Arabia, Egypt and Pakistan. This could largely be attributed to the higher rate of Consanguinity. 8.17 In a another series consanguinity in Pakistan was as high as $68 \%$ in babies with SMN gene deletions. 8 Though the exact prevalence of this condition in Pakistan remains unknown, in our study $32 \%$ of the CVS were done for SMN deletions.

Invasive testing for aneuploidy has been available since the inception of the Foetal Medicine services at the University. In the last couple of years the spectrum of prenatal diagnostic facility has expanded with the introduction of SMN and DMD gene testing locally. Foetomaternal section is a dedicated department to provide monitoring and prenatal diagnosis in our unit. This unit offers first trimester screening, Genetic Sonogram and monitoring of all high risk women with Doppler scan, ultrasound and Preterm delivery screening. Counseling remains a vital part of management of high risk pregnancy. In addition to foetal medicine specialist, we have Paediatric geneticist and counseling services. As prenatal diagnosis is now becoming better, clinicians have to counsel the parents with certain disorders. Counseling remains a challenge in the absence of the region-specific data.

Improvement in laboratory techniques along with the foetal medicine services have largely contributed to improved outcome of pregnancies with poor pregnancy outcome. In the last 18 months, DNA banking has also been started in Aga Khan University. It allows conservation of genetic material and significant amount of DNA for multiple testing of an individual in future. ${ }^{18-20}$ Our study clearly indicates that collaboration with reference laboratories and improvement in DNA extraction can broaden the scope of work. As this improves, the number of patients with undetermined cause of poor pregnancy outcome would decline.

Provision of new diagnostic tests obviously warrants an improvement in the provision of welfare to deserving and non-affording patients. Our unit is working closely with the welfare department to facilitate and help the needy patients. A large number of patients accessing our facility belong to middle /low income strata.

One of the limitations of our study is that the lost to follow up was around $32 \%$. This can be explained by the fact that vast majority of referrals for Prenatal Diagnosis are from outside Karachi. In addition, there is no dedicated nursing staff to collect the follow up. Trained nurses can play a role in counseling and data keeping in such cases.

\section{Conclusion}

Prenatal diagnosis for genetic disorders other than Thalassemia has been made available. This is primarily due the facility of DNA banking. This has led to testing other disorders particularly SMN gene deletion locally. Multidisciplinary input with Genetic Counseling, dedicated specialty personnel and external linkages have improved the scope of this work. Provision of welfare would benefit greater number of patients.

Disclaimer: None to declare.

Conflict of Interest: None to declare.

Funding Sources: None to declare.

\section{References}

1. Aggarwal S, Phadke SR. Medical genetics and genomic medicine in India: current status and opportunities ahead. Mol Genet Genomic Med. 2015; 3:160-71.

2. Qasim I, Ahmad B, Khan MA, Khan N, Muhammad N, Basit S, et al. Pakistan Genetic Mutation Database (PGMD); A centralized Pakistani mutome data source. Eur J Med Genet. 2017; 61:204-8.

3. Afroze B, Lakhani L, Naz F, Somani S, Yunus ZM, Brown N. Challenges identified in the management of patients with inherited metabolic disorders -- A five year experience from Pakistan. Egyp J Med Hum Genet. 2016; 17:259-64.

4. Ansari SH, Shamsi TS, Ashraf M, Bohray M, Farzana T, Khan MT, et al. Molecular epidemiology of beta-thalassemia in Pakistan: far reaching implications. Int J Mol Epidemiol Genet. 2011; 2:403-8.

5. Kanwal S, Bukhari S, Perveen S. Molecular genetics and prenatal diagnosis of beta thalassemia to control transfusion dependent births in carrier Pakistani couples. J Pak Med Assoc. 2017; 67:10304.

6. World Health Organization. The molecular genetic epidemiology of cystic fibrosis. Report of a joint meeting of WHO/ECFTN/ICF (M) A/ECFS. Geneva, WHO. 2004.

7. Crawford TO, Pardo CA. The neurobiology of childhood spinal muscular atrophy. Neurobiol Dis. 1996; 3:97-110.

8. Ibrahim S, Moatter T, Saleem AF. Spinal muscular atrophy: Clinical spectrum and genetic mutations in Pakistani children. Neurol India. 2012; 60:294-8.

9. Wirth B, Herz M, Wetter A, Moskau S, Hahnen E, Rudnik- 
Schoneborn S, et al. Quantitative analysis of survival motor neuron copies: identification of subtle SMN1 mutations in patients with spinal muscular atrophy, genotype-phenotype correlation, and implications for genetic counseling. Am J Hum Genet. 1999; 64:1340-56.

10. American College of Obstetrics and Gynecologists' Committee on Practice Bulletins-Obstetrics: Committee on Genetics; Society for Maternal-Fetal Medicine. Practice Bulletin No. 162: Prenatal Diagnostic Testing for Genetic Disorders. Obstet Gynecol. 2016; 127:e108-22.

11. Jorge $P$, Mota-Freitas MM, Santos R, Silva ML, Soares G, Fortuna AM. A 26-Year Experience in Chorionic Villus Sampling Prenatal Genetic Diagnosis. J Clin Med. 2014; 3:838-48.

12. Royal College of Obstetrician and Gynecologists (RCOG), Amniocentesis and Chorionic Villus Sampling. Green Top Guideline No. 8. 4th Edition. London: RCOG press, 2010.

13. EMORY University School of Medicine. About chorionic villus sampling [Pamphlet]. Department of Human Genetics; Division of Medical Genetics. FS018.2; 2008.

14. Evans $\mathrm{MI}$, Andriole $\mathrm{S}$. Chorionic villus sampling and amniocentesis in 2008. Curr Opin Obstet Gynecol. 2008; 20:164-8.
15. Lunn MR, Wang CH. Spinal muscular atrophy. Lancet. 2008; 371:2120-33.

16. Ogino S, Wilson RB. Spinal muscular atrophy: molecular genetics and diagnostics. Expert Rev Mol Diagn. 2004; 4:15-29.

17. National Institute of Population Studies (NIPS) [Pakistan] and Macro International Inc. june 2008. Pakistan Demographic and Health Survey 2006-07. Islamabad, Pakistan: National Institute of Population Studies and Macro International Inc; [Online] [Cited 2008 June 21]. Available from: URL:https://dhsprogram.com/pubs/pdf/fr200/fr200.pdf]

18. Adams RP. Conservation of DNA: DNA banking. In: Callow JA, Ford-Llyod BV, newbury HJ, eds. Biotechnology and Plant Genetic Resources: Conversation and Use. Biotechnology in Agriculture Series 19. CAB Inter Walling ford UK.163-74.

19. Godard B, Schmidtke J, Cassiman JJ, Ayme S. Data storage and DNA banking for biomedical research: informed consent, confidentiality, quality issues, ownership, return of benefits. A professional perspective. Eur J Hum Genet. 2003; Suppl 2:S88-122.

20. Yates JR, Malcolm S, Read AP. Guidelines for DNA banking. Report of the Clinical Genetics Society working party on DNA banking. J Med Genet. 1989; 26:245-50. 